\title{
The Mineralogy and Geochemistry of the Kamafugitic Três Barras Intrusion, Mata da Corda, Minas Gerais, Brazil
}

\author{
Tompkins L.A. ${ }^{1}$, Taylor, W.R. ${ }^{2}$, Ramsay, R.R. ${ }^{3}$, Armstrong, R. ${ }^{2}$
}

1. Astro Mining N.L., 46 Kings Park Rd, West Perth, 6005 Australia

2. Research School of Earth Sciences, Australian National University, Canberra, ACT 2601, Australia

3. Striker Resources N.L., 256 Adelaide Terrace, Perth, 6000 Australia

Três Barras is a 5 ha oval volcanic pipe (Fig. 1) located five kilometers SW of the town of Presidente Olegário in the state of Minas Gerais, Brazil. The intrusion is exposed along the western erosional edge of the Late Cretaceous volcano-sedimentary Mata da Corda Formation. Alkaline igneous rocks of the Mata da Corda Formation overly and intrude Early Cretaceous, non-volcanic conglomerates, sandstones, and mudstones of the Areado Formation that were deposited under fluviatile conditions. The two formations define the intracratonic São Franciscana Basin that developed on Proterozoic basement of the Bambuí Group. The Três Barras area is of economic significance because drainages emanating from the Serra da Mata da Corda are all diamondiferous. The occurrence of large $(\sim 100$ ct) diamonds in the headwaters of many drainages suggests that primary diamond source rocks are present.

Três Barras pipe consists of an inner weathered magmatic core in the eastern portion that is surrounded by a zone of lapilli tuffs, tuff breccias, and lavas dipping gently to the west (Fig. 1). Late-stage, magmatic facies lavas and dikes intrude the tuffs and breccias. The sandstone country rock appears to be slightly metamorphosed along contacts with the pipe rocks. These features resemble the pipe structures of the leucite lamproite pipes at the West Kimberley, Australia ie. magmatic core and outer tuff ring.

Magmatic rocks from the pipe can be subdivided into either hypabyssal kamafugites or leucitites. The hypabyssal kamafugites are relatively equigranular and coarse-grained. These rocks are dominated by clinopyroxene, perovskite, titanomagnetitie, apatite and phlogopite. Phenocrysts, where present, consist of olivine with reaction rims of phlogopite, zoned clinopyroxene, and perovskite. Fresh kalsilite and rare melilite are only present as inclusions in coarser-grained clinopyroxene. Phillipsite occurs as an alteration product of kalsilite and is common as fine needles in the groundmass and as inclusions in clinopyroxene.

The Leucitites generally have flow-aligned textures and are characterized by phenocrysts of twinned and zoned clinopyroxene, poikilitic phlogopite, perovskite, and olivine pseudomorphed by serpentine. Glomerocrysts composed of clinopyroxene, phlogopite and apatite are present in some samples. Groundmass phases include leucite, K-feldspar, clinopyroxene, perovskite, titanomagnetite with aegirine and/or richterite rims and rare priderite.

Fresh olivine is only present in the hypabyssal kamafugite (TB-5; Fig. 1). Compositions range from mg\# 82.5 to 85.5 , and ocassionally up to 89. Some grains are zoned and show an increase in FeO, $\mathrm{CaO}$ and $\mathrm{MnO}$ towards the rim. Rare olivine may occur as inclusions in clinopyroxene. 
Clinopyroxenes are variable in composition and show an increase in $\mathrm{Na}$ and $\mathrm{Ti}$ towards the rims. Coarse phenocrysts have $\sim 1.0 \quad \mathrm{wt} \% \quad \mathrm{TiO}_{2}$ and low $\mathrm{Al}_{2} \mathrm{O}_{3}$ typical of lamproitic diopsides. Groundmass pyroxenes in the leucitites may have significant solid solution towards aegirine.

Phenocrysts and glomerocrysts of phlogopite have mg\# $\sim 80$ and cores with $\mathrm{TiO}_{2} \sim 5-6$ wt $\%$ and $\mathrm{Al}_{2} \mathrm{O}_{3} \sim 12-14 \mathrm{wt} \%$. The rims show a decrease in $\mathrm{Al}_{2} \mathrm{O}_{3}$ to $\sim 8 \mathrm{wt} \%$. Amphiboles, which are restricted to the leucitites, usually occur as rims on phenocrystic clinopyroxene or olivine and in the latter case the amphiboles are associated with phlogopite. The amphiboles are predominantly $\mathrm{K}$ richterite with $4-5 \mathrm{wt} \% \mathrm{~K}_{2} \mathrm{O}$ and $0.6-5.0 \mathrm{wt} \% \mathrm{TiO}_{2}$.

Perovskite is the most abundant titanate phase and contains up to 2.0 wt $\% \mathrm{Ce}_{2} \mathrm{O}_{3}$, typically $\sim 0.5$ wt $\% \mathrm{SrO}$ and $0.5 \mathrm{wt} \% \mathrm{Nb}_{2} \mathrm{O}_{5}$. Titanomagnetite is the most abundant spinel with $\sim 4-18 \mathrm{wt}^{\circ} \mathrm{TiO}_{2}$ and some grains contain up to $6 \mathrm{wt} \% \mathrm{MnO}$ and $1.0 \mathrm{wt} \% \mathrm{ZnO}$.

The Três Barras pipe will be dated by the SHRIMP U/Pb method on perovskite from kamafugite sample TB-5.

The Três Barras rocks are silica-undersaturated with the leucitites varying between $42-47 \mathrm{wt} \%$ and the kamafugites $\sim 38 \mathrm{wt} \% \mathrm{SiO}_{2}$. The rocks vary from relatively primitive (mg\#=64-68) to olivinefractionated variants with $\mathrm{mg \#} \sim 50$. Least altered leucitites and kamafugites are potassic to ultrapotassic, the highest $\mathrm{K}_{2} \mathrm{O}$ content is $6.8 \mathrm{wt} \%$ in the TB-4 leucitite. The rocks are characterized by high $\mathrm{TiO}_{2} / \mathrm{Al}_{2} \mathrm{O}_{3}$ ratios $(\sim 0.6$ for leucitites and $\sim 1.0$ for kamafugites) and high $\mathrm{CaO}$ contents (typically $\sim 14 \mathrm{wt} \% \mathrm{CaO}$ ). Some incompatible elements have extreme abundances such as $\mathrm{Ba}$ (up to $5.0 \mathrm{wt} \% \mathrm{BaO}$ ), $\mathrm{Sr}$ (up to 2,000 ppm), Ce (up to $680 \mathrm{ppm}$ ) and $\mathrm{Nb}$ (up to $300 \mathrm{ppm}$ ). REE abundances fall in the range typical for kimberlites and lamproites although chondrite normalized $\mathrm{La} / \mathrm{Lu}$ ratios are lower $(\sim 80)$ compared to many kimberlites and lamproites which typically have ratios $>150$. Trace element abundance patterns for the Três Barras leucitites are very similar to fresh ugandite lavas from the S.W. Uganda kamafugitic province except for greater Ba enrichment in the former.

The rocks are characterized by moderate $\mathrm{Nb} / \mathrm{Zr}$ ratios $(\sim 0.4)$ which are similar to that found in other Late Cretaceous-Eocene potassic alkaline rocks from central Brazil and alkali basalts from the Rio Grande Rise and Tristan da Cuhna hot spots. The Late Cretaceous-Eocene timing of alkaline volcanism in this part of Brazil suggests that this igneous activity is not directly related to the passage of the Tristan Da Cuhna hot spot as proposed for the generation of the $\sim 130$ Ma Parana flood basalts. However, the igneous activity is perhaps related to another hot spot (the Trinidade or Martin Vaz plume) which has modelled trails that pass just to the north of the Mata da Corda at 85 Ma (O'Connor and Duncan, 1990). Anomalous kamafugitic chemistry may either reflect smalldegree melting of enriched lithosphere beneath SE Brazil, or it may be a source feature relating to the mantle plume itself.

Similarities between the Três Barras kamafugite and leucite lamproites of Western Australia suggest that a kamafugitic analogue of diamondiferous olivine lamproites could be present in the Mata da Corda region, perhaps as an early phase of volcanicity. Such olivine kamafugite pipes could be the enigmatic sources of alluvial diamonds in the region. 


\section{References}

O'Connor, J.M. and Duncan, R.A., 1990, Evolution of the Walvis Ridge-Rio Grande Rise hot spot system: Implications for African and South American plate motions over plumes, Journal of Geophysical Research, vol. 95, no. B11, 17,475 - 17,502.

\section{Acknowledgments}

Part of this research was supported by a special research grant from CRA Exploration (now Rio Tinto), Perth, Australia.

\section{THE TRES BARRAS KAMAFUGITIC INTRUSION}

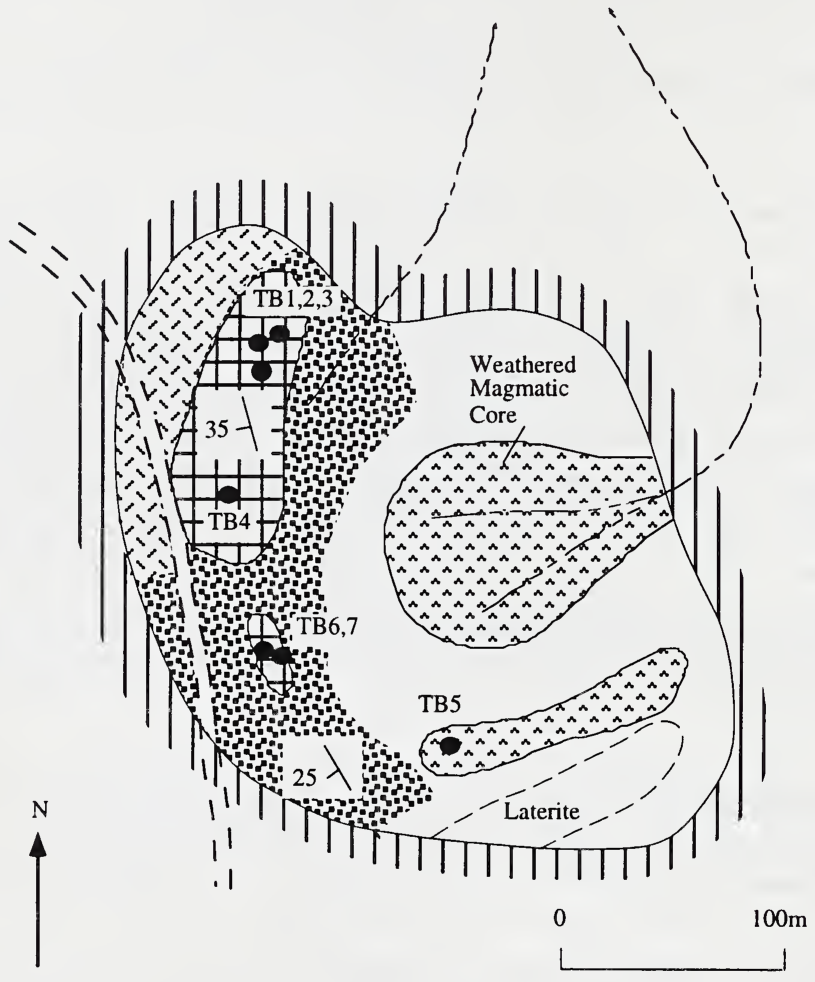

KEY

Cpx-Ol-phyric magmatic rock

Cpx-Phlog-Cpx phyric

magmatic rock (rare dykes)

Lapilli tuff and tuff-breccia

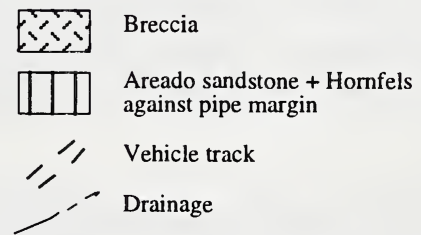

Figure 1. Geologic map of the Três Barras Intrusion with location of samples. 